\title{
Reinforced concrete ribbed slabs with wide-beam
}

\section{Lajes nervuradas de concreto armado com viga-faixa}
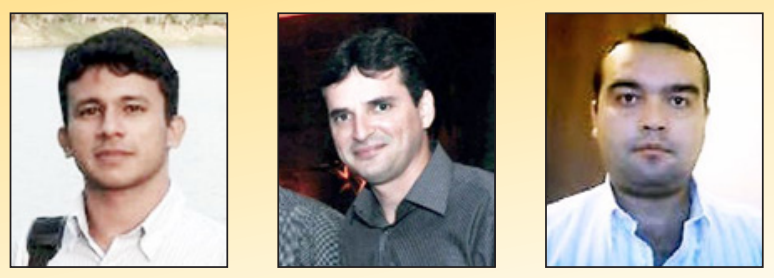

P. V. P. SACRAMENTO paulo.sacramento@ifap.edu.br

M. S. PICANÇO marcelosp@ufpa.br

D. R. C. OLIVEIRA denio@ufpa.br

\begin{abstract}
Ribbed slabs have been widely used in buildings due to their many advantages, especially the decrease of concrete below the neutral line. This paper presents an experimental and computational study on ribbed slabs with wide-beam, two one-way slabs and two two-way slabs, with variable depths were tested to evaluate their resistance to punching and shear strength of slabs. Experimental and computational results showed that the wide-beam ribs connection is a critical point in the design of the slabs due to the difference in stiffness in the transition zone. Best results for the ultimate load estimates for ribs were provided by EC 2 (2004), while estimates of ACI 318 (2008) and NBR 6118 (2014) were respectively conservative and unsafe. Test results on slabs also revealed that the Brazilian alternative to analysis ribbed slabs as solid ones failed to give satisfactory results.
\end{abstract}

Keywords: ribbed slabs, reinforced concrete, ribs, wide-beam.

\section{Resumo}

As lajes nervuradas têm sido largamente utilizadas devido às suas diversas vantagens, especialmente à redução de concreto abaixo da linha neutra. Este artigo apresenta um estudo experimental e computacional sobre lajes nervuradas com viga-faixa, sendo duas bidirecionais e duas unidirecionais, ensaiadas para avaliar a resistência à punção e ao cisalhamento das lajes. Os resultados, tanto experimentais como computacionais, mostraram que a ligação viga-faixa-nervuras é um ponto crítico de projeto devido à diferença de rigidez na zona de transição. Os melhores resultados para estimar a resistência última das lajes foi fornecido pelo EC 2 (2004), enquanto as estimativas da ACl 318 (2008) e da NBR 6118 (2014) foram, respectivamente, conservadoras e contra a segurança. Os resultados dos testes também mostraram que a recomendação da norma brasileira em adotar procedimentos de análise das lajes nervuradas como lajes maciças não forneceram resultados satisfatórios.

Palavras-chave: lajes nervuradas, concreto armado, nervuras, viga-faixa. 


\section{Introduction}

One of the most important decisions in the building design process is the type of slab used. Slabs represent a significant consumption of concrete in the case of buildings with multiple floors. According to Schwetz [1], the volume of concrete in solid slabs may comprise up to two-thirds of the structure's total volume. In this context, ribbed slabs represent a good option since, according to Macgregor [2], the relationship between the distribution of shear stress, bending moment and length of the slab span is an important parameter to determine the type of slab. In the case of longer spans (from 6 meters), the necessary thickness of a flat slab to transmit the slab's shear forces to the column may exceed the thickness required to resist the bending forces. So that the material consumption and bending moments on the slab due to its dead weight could be reduced, part of the concrete at mid-span may be eliminated and the thickness in the region of the support must be maintained. The main advantages of ribbed slabs are low volume of concrete (although the slab's overall depth is bigger), reduced dead weight and improvement of formwork system for casting, facilitating assembly and streamlining work. However, the system also has its disadvantages, particularly low rigidity and ductility, if employed in seismic areas, mentioned by Climent and Avila [3], and a reduction in overall stability of the horizontal forces, reducing the diaphragm effect contribution.

The compression flange coupling the ribs functions as a part of a $T$ beam - called collaborative flange - stiffening ribs in the positive moment region of the slab. However, in the negative moment region, normally in the region on the support where the concrete flange would be tensioned, the use of a ribbed region becomes impracticable from the point of view of connection security and stiffening is recommended. Stiffening may be carried out by alternatives as drop panels, capitals or insertion of reinforced concrete wide-beams interconnecting the columns. The use of wide-beams is well accepted by structure designers since they provide a simple formwork and supporting systems, coupled to the ease of inlay of horizontal pipes at the bottom surface of the slab. In some design situations, it is necessary to increase the widebeam height to avoid excessive displacements in span, to avoid checking the punching shear and combat high bending moments in the slab-column connection. Figure 1 shows a type of widebeam thickening. However, useful information is still scanty in the literature. Current study, such as Lau and Clark [4], assesses the performance of one and two-way ribbed slabs with wide-beams by analyzing the structural behavior of the wide-beam-column connection and the behavior of the wide-beam-ribs connection when variations in wide-beam depth occur. Finally, several conclusions on this type of slab under high loadings are presented.

\subsection{Justification}

Despite the conventional system with solid slabs supported by beams still widely employed, the structural system with ribbed slabs supported on wide-beams has been very popular in Brazil, especially in the case of buildings where large spans must be overcome. Research in this area is greatly relevant to assess, for instance, the behavior of the solid region and the spacing between the ribs, which usually generate doubts during the design phase, since the code's prescriptions, such as NBR 6118 [5], overlook the effects of torsion in ribs and stress concentration on the rib-solid region connection, described by Soares [6], Souza [7], Albuquerque [8] and Souza [9]. The Brazilian code, for example, proposes that ribbed slabs are checked, or solid slabs are considered, or beams based on the limits of spacing between the ribs are considered. Nevertheless, studies by Al-Bayati [10] have shown that checks suggested for the system, based on the concepts of a solid slab, are not fully applicable since the dimensions of the wide-beam directly imply the type of slab failure. In fact, a failure may occur in some cases by punching shear in wide-beam-column connection. It would be a design delimiter for ribbed slabs since these wide-beams are only dimensioned to resist the bending moment and beam shear.

\section{Code's prescriptions}

\subsection{General aspects about ribbed slabs}

\subsubsection{ACI $318(2008)$}

The US building code $\mathrm{ACI} 318$ [11] defines some basic parameters of construction provisions on ribbed slabs. The code recommends that the ribs should have a width $\left(b_{w}\right)$ not greater than $100 \mathrm{~mm}$; depth up to 3.5 times the minimum ribs' width and spacing between the ribs' faces (s) not greater than $750 \mathrm{~mm}$. The flange's thickness should be at least $37.5 \mathrm{~mm}$ and at the most comply with the ratio (s/12), or it may be $62.5 \mathrm{~mm}$ thickness.

\subsubsection{Eurocode 2 (2004)}

Recommendations on ribbed slabs proposed by EC2 [12] include criteria on slab treatment. When ribs and flange of the ribbed slab

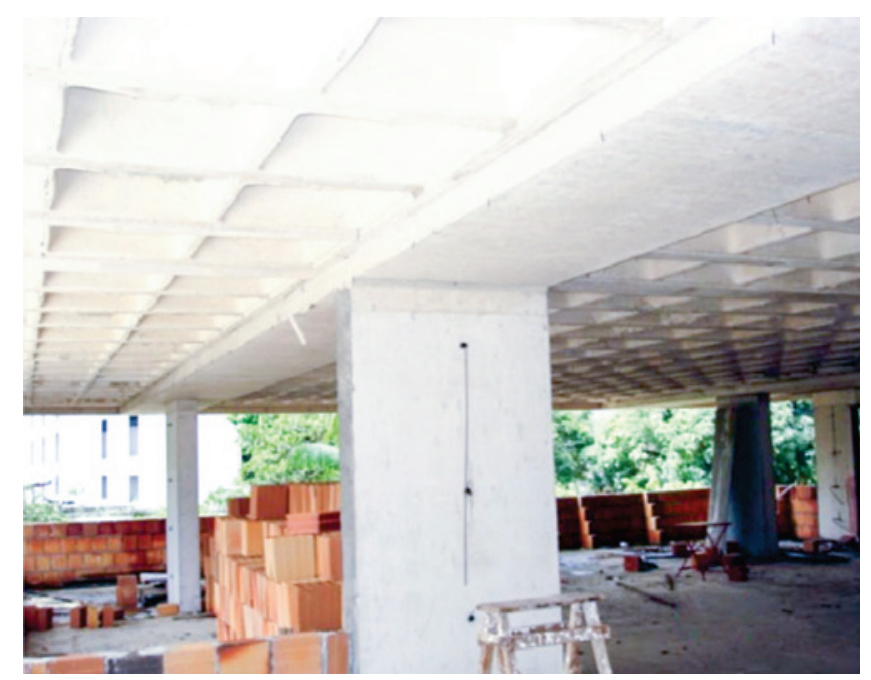

Figure 1

Recommended peak acceleration for human comfort for vibrations due to human activities (AISC Steel Design Guides Series 11; Allen e Murray, 1993; ISO 2631-2: 1989) 
have sufficient torsional stiffness, these elements may not be checked separately. However, the checking of recommendations for solid slabs may be applied when the two slab types have similar behavior. This prescription will be valid when the following conditions are met:

- The spacing of the ribs $\left(\mathrm{s}_{\mathrm{n}}\right)$ should not exceed $1500 \mathrm{~mm}$;

- The rib's depth $(\mathrm{h})$, from the lower surface to the flange, should not exceed four times its width;

- The flange depth $\left(\mathrm{h}_{\mathrm{f}}\right)$ must have at least $\mathrm{s}_{\mathrm{n}} / 10$ or $50 \mathrm{~mm}$, always selecting the highest.

\subsubsection{NBR 6118 (ABNT, 2014)}

Recommendations for ribbed slabs in the Brazilian code NBR 6118 [5] are brief. In the case of design recommendations, the code recommends certain conditions, described below:

When spacing between the axes of the ribs $(I)$ is less or equal to $650 \mathrm{~mm}$, the verification of the flange bending may be unnecessary; the adoption of slab criteria in checking the shear in the region of the ribs is enough;

- When spacing between the axes of the ribs $(I)$ ranges between 650 and $1100 \mathrm{~mm}$, flange bending must be checked and ribs should be dimensioned as beams. The check as slab may still be performed if the spacing between the ribs is up to $900 \mathrm{~mm}$ and the ribs are wider than $120 \mathrm{~mm}$ on an average;

- When spacing between the axes of ribs $(I)$ is greater than $1100 \mathrm{~mm}$, the flange should be checked as slab, supported on beams, complying with minimum spacing limits.

\subsection{Shear strength}

\subsubsection{ACI 318 (2008)}

$\mathrm{ACl}$ code recommends that shear strength is taken as the average of the shear stresses acting over the cross section $b_{w} \cdot d$. In the case of elements without shear reinforcement, the shear resistance should comply only with the concrete compression strength in the section under analysis. In the case of elements with shear reinforcement, the element's strength is given by the concrete strength parcel plus the contribution of the transversal shear reinforcement. Thus, the shear strength of a reinforced concrete element with transversal shear reinforcement is calculated by Equation 1 .

$\emptyset \cdot V_{n} \leq V_{c}+V_{s}$

Where,

$\mathrm{V}_{\mathrm{n}}=$ nominal shear strength reduced by factor $\varnothing$;

$\mathrm{V}_{\mathrm{c}}=$ shear strength provided by the concrete, calculated by Equation 2, in simplified form, valid for members subjected to a combination of bending moment and shear only;

$\mathrm{V}_{\mathrm{s}}=$ strength from the shear reinforcement, calculated by Equations 3 (stirrups arranged vertically) and 4 (inclined stirrups).

$V_{c}=\frac{1}{6} \cdot \sqrt{f^{\prime}} \cdot b_{w} \cdot d$

Where,

$\mathrm{f}^{\prime}{ }_{\mathrm{c}}=$ concrete compressive strength limited to $70 \mathrm{MPa}$;

$b_{w}=$ width of the cross section under analysis; $\mathrm{d}=$ effective depth of the cross section.

$V_{s}=\frac{A_{v} \cdot f_{y t} \cdot d}{s}$

$V_{s}=\frac{A_{v} \cdot f_{y t} \cdot(\sin \alpha+\cos \alpha) \cdot d}{s}$

In Equations 3 and 4,

$A_{v}=$ steel cross section area of the shear reinforcement;

$\mathrm{f}_{\mathrm{yt}}=$ yield stress of the shear reinforcement;

$\alpha=$ inclination angle of the shear reinforcement;

$\mathrm{s}=$ spacing between stirrups.

\subsubsection{Eurocode 2 (2004)}

Eurocode recommends that in areas where verification meets condition shown in Equation 5, the resistant portion of the shear reinforcement may be discarded, although minimum shear reinforcement should be provided. Thus, the shear strength of a concrete element without shear reinforcement may be calculated by Equation 6 .

$V_{E d} \leq V_{R d, c}$

$V_{R d, c}=0.18 \cdot \xi \cdot\left(100 \cdot \rho_{l} \cdot f_{c k}\right)^{\frac{1}{3}} \cdot b_{w} \cdot d$

In Equations 5 and 6 ,

$V_{E d}$ is the shear force due to external load;

$\xi=(1+\sqrt{200 / d}) \leq 2.0$, with the value of $d$ in $\mathrm{mm} ;$

$\rho_{1}=$ longitudinal reinforcement ratio not greater than 0.02 .

When the condition imposed in Equation 6 is not satisfied, i.e. when $V_{R d, c}$ is not sufficient to resist the external shear forces, a shear reinforcement should be added. In this case, the resistant portion of the shear reinforcement is calculated by Equation 7 or 8 for inclined or vertical stirrups, respectively.

$V_{s}=\frac{A_{s w}}{s} \cdot z \cdot f_{y w d} \cdot \cot \theta$

$V_{s}=\frac{A_{s w}}{s} \cdot z \cdot f_{y w d} \cdot(\cot \theta+\cot \alpha) \cdot \sin \alpha$

\subsubsection{NBR 6118 (ABNT, 2014)}

For solid and ribbed slabs without shear reinforcement, the shear strength may be calculated by Equation 9 .

$V_{R d 1}=\left[\tau_{R d} \cdot k \cdot\left(1.2+40 \cdot \rho_{1}\right)\right] \cdot b_{w} \cdot d$

Where,

$\tau_{\mathrm{Rd}}=0.25 \cdot \mathrm{f}_{\mathrm{ctd}}$;

$\mathrm{f}_{\text {ctd }}=\mathrm{f}_{\text {ctk,inf }} / \gamma_{\mathrm{c}}$

$\mathrm{f}_{\mathrm{ctk}, \mathrm{inf}}=$ lower characteristic tensile strength of concrete;

$\mathrm{k}=1.6-\mathrm{d}$, with $\mathrm{d}$ given in meters;

$\rho_{1}=\frac{A_{s 1}}{b_{w} \cdot d} \leq 0.02$, where $\mathrm{A}_{\mathrm{s} 1}$ is the longitudinal tensile reinforcement area;

$b_{w}=$ cross section's minimum width along effective depth $d$.

Since the compressed concrete diagonal (strut) must also be complied with, the code recommends that strength strut should be calculated according to Equation 10. 
$V_{S d} \leq V_{R d 2}=0.27 \cdot \alpha_{v 1} \cdot f_{c d} \cdot b_{w} \cdot d$

In Equation 10, $\alpha_{v 1}=\left(1-\frac{f_{c k}}{250}\right)$

In the case of failure by tensile of the concrete diagonal, the code recommends that the strength part to resist the shear force in elements without shear reinforcement must be calculated by Equation 11. In this case, the resistant portion refers to the section in simple flexural or flexural-tension with the neutral axis through the section. When shear reinforcement becomes necessary, the resistant portion of this transverse reinforcement may be calculated by Equation 12 .

$V_{c 0}=0.6 \cdot f_{c t k} \cdot b_{w} \cdot d$

$V_{s w}=\left(\frac{A_{s}}{s}\right) \cdot 0.9 \cdot d \cdot f_{y w d} \cdot(\sin \alpha+\cos \alpha)$

Where,

$\mathrm{V}_{\mathrm{c} 0}=$ reference value for $\mathrm{V}_{\mathrm{c}}$, which represents the portion of shear force resisted by mechanisms complementary to the trust model; $\mathrm{f}_{\mathrm{ctk}, \text { inf }}=$ lower characteristic tensile strength of concrete;

$b_{w}=$ cross-section's minimum width along useful depth $d$.

$\mathrm{V}_{\mathrm{sw}}=$ portion of shear force resisted by stirrups;

$A_{\text {sw }}=$ cross-section's area of stirrups;

$\mathrm{s}=$ spacing of stirrups;

$\mathrm{f}_{\mathrm{ywd}}=$ yield strength of shear reinforcement;

$\alpha=$ inclination of stirrups.

\subsection{Punching shear strength}

\subsubsection{ACI 318 (2008)}

$\mathrm{ACl}$ supposes that shear stress acting at both directions of a slab cross section is a function of the compressive strength of concrete and the relationship of the column's dimensions and the effective depth of the slab. Shear stress must be verified in a region spaced $d / 2$ of the column faces, taken as the critical perimeter $\mathrm{b}_{0}$ where the stress acts (Figure 2). The punching shear strength $\mathrm{V}_{c}$ is calculated by Equations 13, 14 and 15, adopting the lower value.

$V_{c}=0.17 \cdot\left(1+\frac{2}{\beta_{c}}\right) \cdot \sqrt{f^{\prime}} \cdot b_{0} \cdot d$

$V_{c}=0.083 \cdot\left(\frac{\alpha_{s} \cdot d}{b_{0}}+2\right) \cdot \sqrt{f^{\prime}} \cdot b_{0} \cdot d$

$V_{c}=0.33 \cdot \sqrt{f^{\prime}} \cdot b_{0} \cdot d$

In Equations 13, 14 and 15:

$\beta_{c}=$ ratio between the largest and the smallest side of the column;

$\mathrm{f}^{\prime}{ }_{\mathrm{c}}=$ compressive strength of concrete $\leq 70 \mathrm{MPa}$;

$d=$ effective depth of the slab;

$\mathrm{b}_{0}=$ critical perimeter around the column;

$\alpha_{s}=$ constant that varies with the number of sides inserted into the critical section of the slab (40 for internal columns; 30 for edge columns; 20 for corner columns).

\subsubsection{Eurocode 2 (2004)}

The European code proposes a model for punching shear checking at the last limit state, corresponding to the resulting force of a concentrated load in a relatively small area. The area around the load is bounded by a perimeter called control perimeter $u_{1}$. The code recommends that it may be taken at a distance $2 \mathrm{~d}$ from the face of the loaded area (Figure 2). The checking of the punching shear strength of a concrete slab without punching shear reinforcement should be performed under this code, in a control section, and calculated by Equation 16. Rates $\xi$ and $\rho_{1}$ in this equation are limited to avoid unsafe results.

$V_{R d, c}=0.18 \cdot \xi \cdot\left(100 \cdot \rho_{l} \cdot f_{c k}\right)^{\frac{1}{3}} \cdot b_{w} \cdot d$

In Equation 16,

$\xi=(1+\sqrt{200 / d}) \leq 2.0$, with $\mathrm{d}$ in $\mathrm{mm}$;

$\rho_{1}=$ longitudinal reinforcement ratio not greater than 0.02 ;

$\mathrm{f}_{\mathrm{ck}}=$ compressive strength of concrete in $\mathrm{MPa}$;

$\mathrm{u}_{1}=$ critical perimeter, calculated from $2 \mathrm{~d}$ to the face of column;

$\mathrm{d}=$ effective depth of the slab.

\subsubsection{NBR 6118 (ABNT, 2014)}

The Brazilian code on the calculation of strength to punching shear of reinforced concrete slabs basically features the same criteria used by design code EC 2 [12], with the difference that it does not limit the amount of size effect $(\xi)$; for rates greater than 2.0 , there is an increase in strength capacity to punching shear and rate of the flexural reinforcement ratio $\left(\rho_{\mathrm{l}}\right)$ is not limited to 0.02 .

\section{Experimental program}

\subsection{Characteristics and monitoring of slabs}

So that the structural behavior and ultimate strength of ribbed
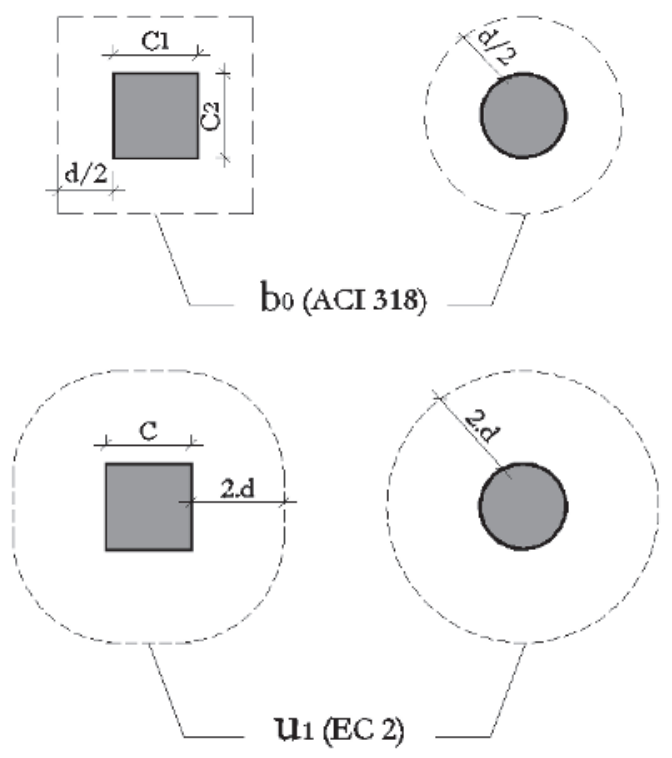

Figure 2

Critical perimeter according to $\mathrm{ACl} 318$ [11] and EC 2 [12] 
Table 1

Slabs' main characteristics

\begin{tabular}{|c|c|c|c|c|c|c|c|c|c|c|}
\hline Slab & Type & $\begin{array}{l}I_{x}=I_{y} \\
(\mathrm{~mm})\end{array}$ & $c(\mathrm{~mm})$ & $f_{c k}(M P a)$ & $\mathrm{h}_{\mathrm{wb}}(\mathrm{mm})$ & $\begin{array}{l}d_{w b}^{*} \\
(m m)\end{array}$ & $\begin{array}{l}d^{* *} \\
(\mathrm{~mm})\end{array}$ & $\rho_{x}(\%)$ & $\rho_{\mathrm{y}} \quad(\%)$ & $\begin{array}{l}\text { Ribs' shear } \\
\text { reinforcement }\end{array}$ \\
\hline L1 & \multirow{2}{*}{ One-way } & \multirow{4}{*}{2200} & \multirow{4}{*}{200} & \multirow{4}{*}{31} & 150 & 115 & \multirow{4}{*}{115} & \multirow{4}{*}{1.06} & 0.74 & - \\
\hline L2 & & & & & 150 & 115 & & & 0.74 & \multirow{3}{*}{$\begin{array}{c}\text { TR } 8644 \\
\text { Belgo }\end{array}$} \\
\hline L3 & \multirow{2}{*}{ Two-way } & & & & 200 & 176 & & & 0.48 & \\
\hline L4 & & & & & 250 & 226 & & & 0.38 & \\
\hline
\end{tabular}

slabs with wide-beam could be assessed, four slabs supported on square columns with sides of $200 \mathrm{~mm}$ and thickness of $50 \mathrm{~mm}$ positioned at the centre of the slabs were moulded. The slabs' sides measured $2200 \mathrm{~mm}$ and $150 \mathrm{~mm}$ thickness. The dimensions adopted for the slabs were defined according to the idealization of the distribution of the negative bending moment in the region around the column, where the maximum bending moments and the maximum shear stresses occur.

Two slabs were supported on both edges of the $x$ direction only, with load application at the centre (one-way slabs). The other two slabs were supported in the centre (column) and the load was applied at the four edges (two-way slabs). The choice of two slabs of each model was considered in this research as an adequate number to evaluate the behavior of ribbed slabs, although a larger number of elements could provide more information about the subject. The main variable was the variation of the wide-beam depth $\left(\mathrm{h}_{\mathrm{wb}}\right)$, its width was constant and equal to $750 \mathrm{~mm}$ for all slabs. The wide-beams measured $150 \mathrm{~mm}, 200 \mathrm{~mm}$ or $250 \mathrm{~mm}$.

The ribs were set only at one direction, each $80 \mathrm{~mm}$ wide and $100 \mathrm{~mm}$ high each, with spacing between ribs' axes equal to 530 $\mathrm{mm}$, connected by a flange $50 \mathrm{~mm}$ thickness. It is important to emphasize that the spacing between the ribs was adopted as inferior to the minimum required by the standards evaluated so that the ribs are not verified as beams but as slabs, where $\mathrm{s} \leq 65 \mathrm{~mm}$ for NBR 6118, $\mathrm{s} \leq 1500 \mathrm{~mm}$ for EUROCODE and $\mathrm{s} \leq 1500 \mathrm{~mm}$ for $\mathrm{ACl}$ 318. Three slabs presented shear reinforcement of TR 8644 on the ribs, with inclination angle $\alpha$ equal to $38.6^{\circ}$. Table 1 presents the general data of the four slabs and Figure 3 shows, respectively, the plan view and cross sections of the slab.

The flexural reinforcement was composed of CA-50 $\left(f_{y s}=500 \mathrm{MPa}\right)$ steel bars with diameters of $12.5 \mathrm{~mm}$ and $20.0 \mathrm{~mm}$ distributed on the slabs' top surface. The $12.5 \mathrm{~mm}$ diameter steel bars were placed in the direction of the ribs ( $x$ direction) and the $20.0 \mathrm{~mm}$ diameter ones were arranged in the direction of the wide-beam ( $y$ direction). Figure 4 shows a schematic and true positioning of the bars on the slabs. Five CA-50 steel bars, diameter $6.3 \mathrm{~mm}$, were used as distribution reinforcement at each side parallel to the wide-beam.

Only three of the four slabs had shear reinforcement in the ribs. The truss-type reinforcement, called TR8644-Belgo, from Arcelor Mittal, is widely used in the manufacture of trussed beams and trussed pre-slabs. Bars are CA-60 $\left(f_{y s}=600 \mathrm{MPa}\right)$ type formed by an upper longitudinal bar $(6.3 \mathrm{~mm})$, two bottom longitudinal bars $(6.3 \mathrm{~mm})$ connected by sinusoidal-shaped stirrups $(4.2 \mathrm{~mm})$ measuring $80 \mathrm{~mm}$ in depth (h) and an inclination angle of $38.6^{\circ}$.

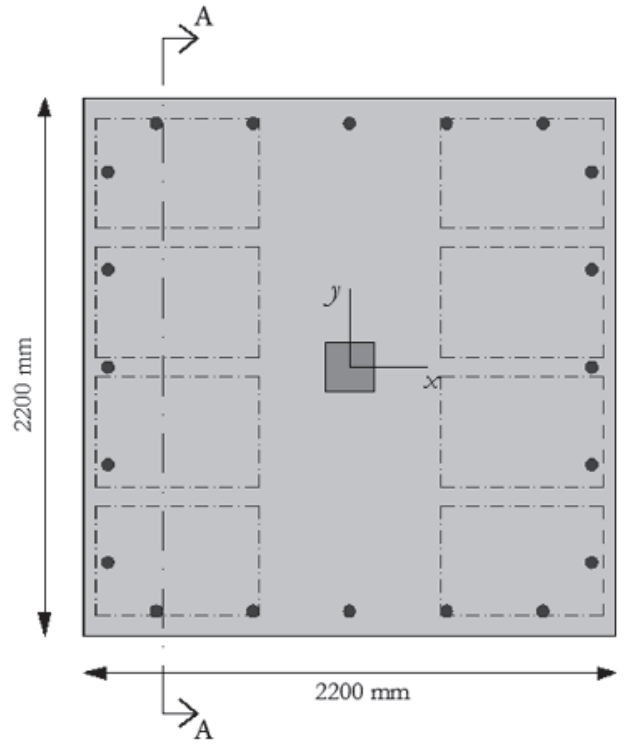

Figure 3

Slabs' dimensions of the series under study
Section A L1

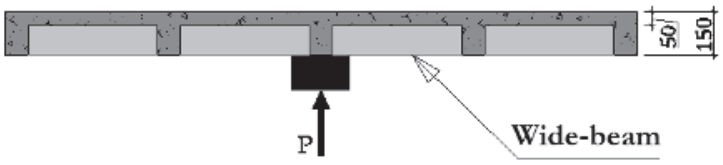

Section A L4

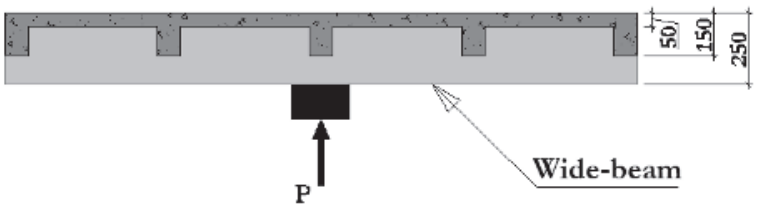



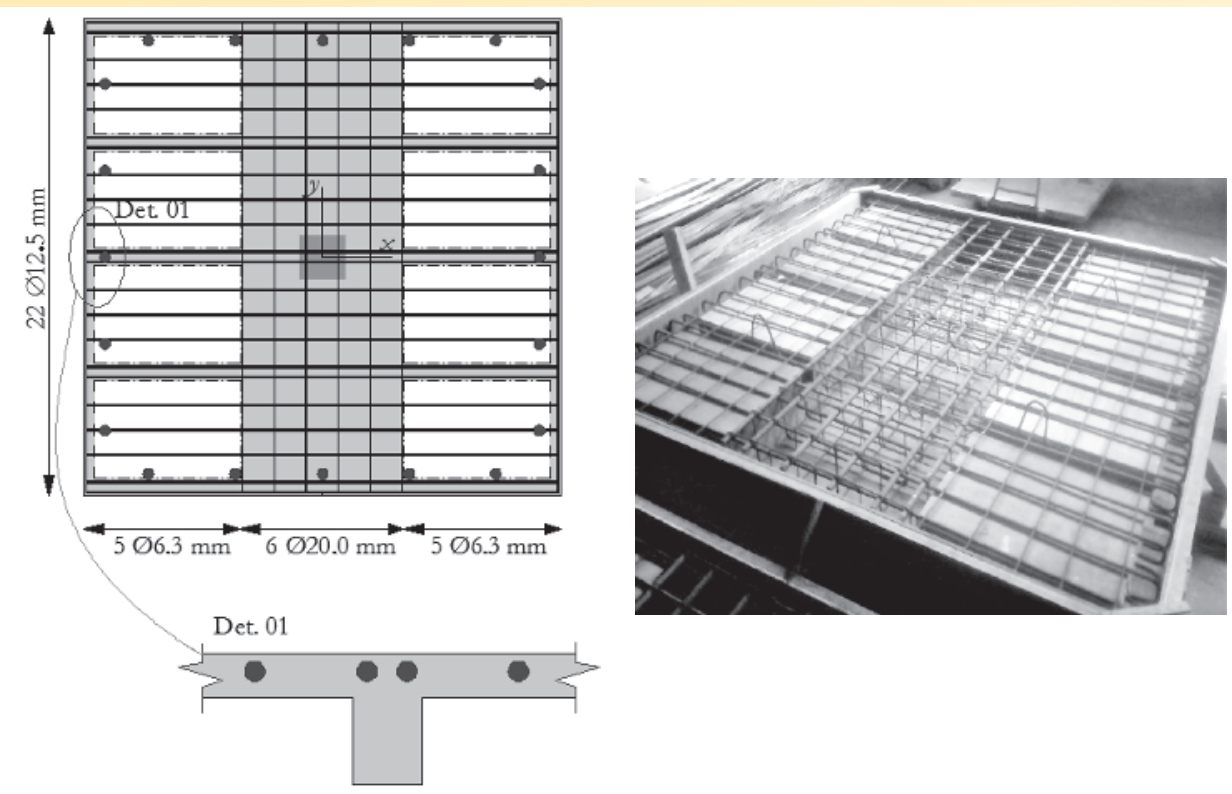

Figure 4

Slabs' flexural reinforcement details

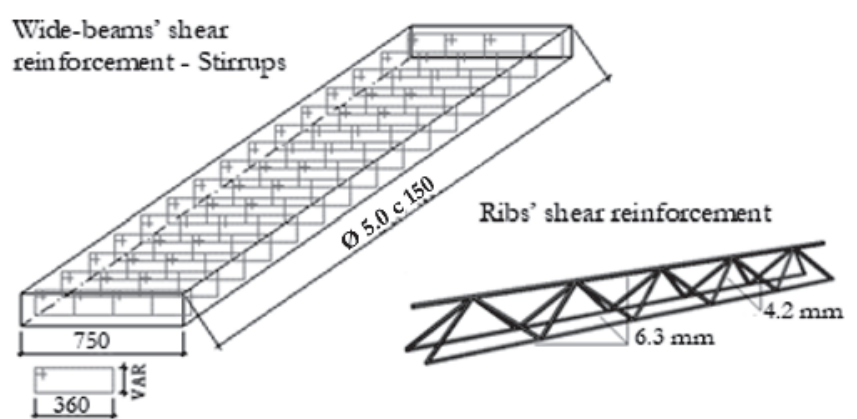

\section{Figure 5}

Slabs' trussed shear reinforcement

Figure 5 shows a perspective view of shear reinforcement.

Shear reinforcement also was used in the wide-beam, composed of CA-60 steel bars with $5.0 \mathrm{~mm}$ diameter. They were positioned along the wide-beam and spaced at $150 \mathrm{~mm}$. Reinforcement

simulated the behavior of a real structure since within a design situation the reinforcement is usually dimensioned to resist the shear forces. There is no doubt about the contribution of this reinforcement on the punching strength of the wide-beam-column connection and the spread of forces to ribs. Figure 5 shows the wide-beam's reinforcement arrangement.

Six dial gages were placed on one-way slabs and seven on twoway slabs to register vertical displacements. Four were arranged on the one-way slabs at $x$ direction and two at $y$ direction. Further, four were employed in the two-way slabs at $x$ direction and three at $y$ direction, spaced $250 \mathrm{~mm}$. Figure 6 demonstrates the plan of the dial gages arrangement for one-way and two-way slabs. Reinforcement and concrete's strains were monitored by strain gauges (EERs) positioned at the side (middle depth) of the steel bars along the longitudinal axis to minimize the effects from local flexure and on the concrete's compressed surface, i.e. the bottom surface, far $d / 2$ from the column face, within the critical region, following $\mathrm{ACI} 318$ [11]. These strain gauges were
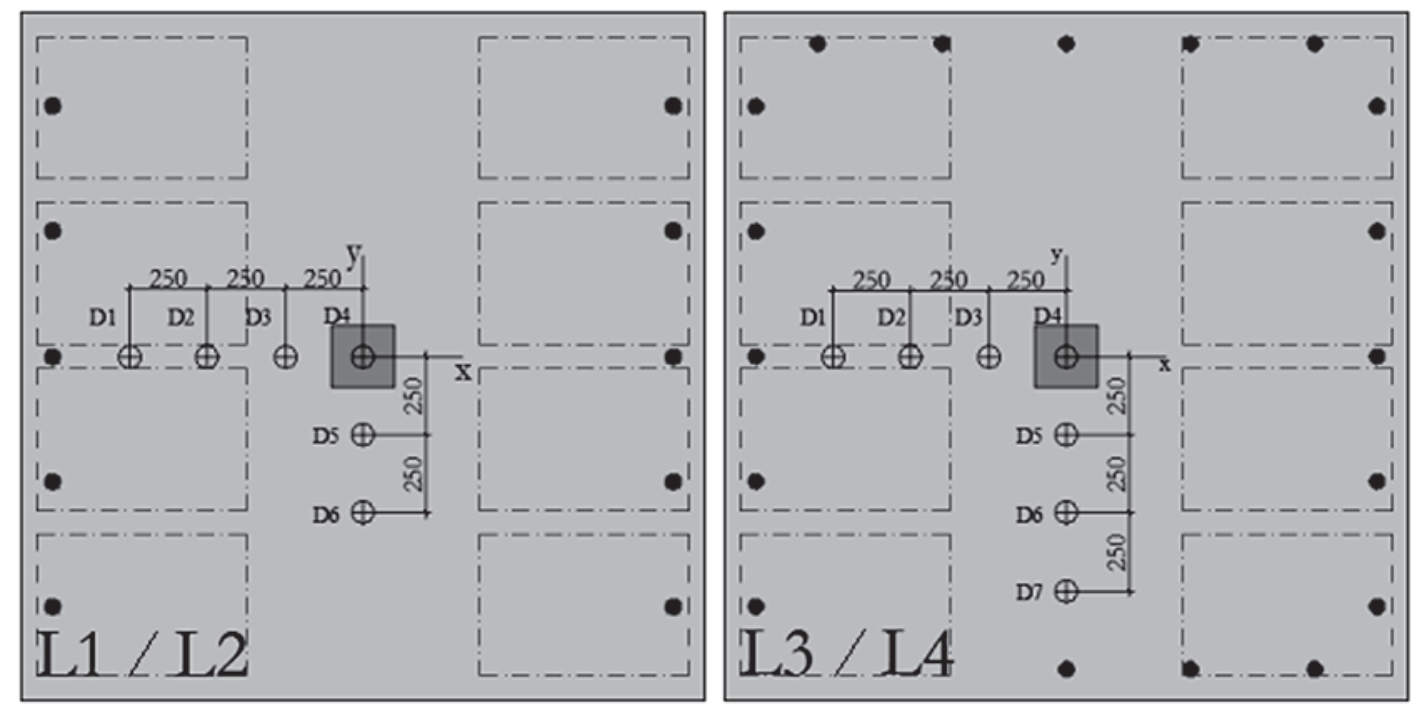

Figure 6

Positioning of the digital dial gauges on the slabs 

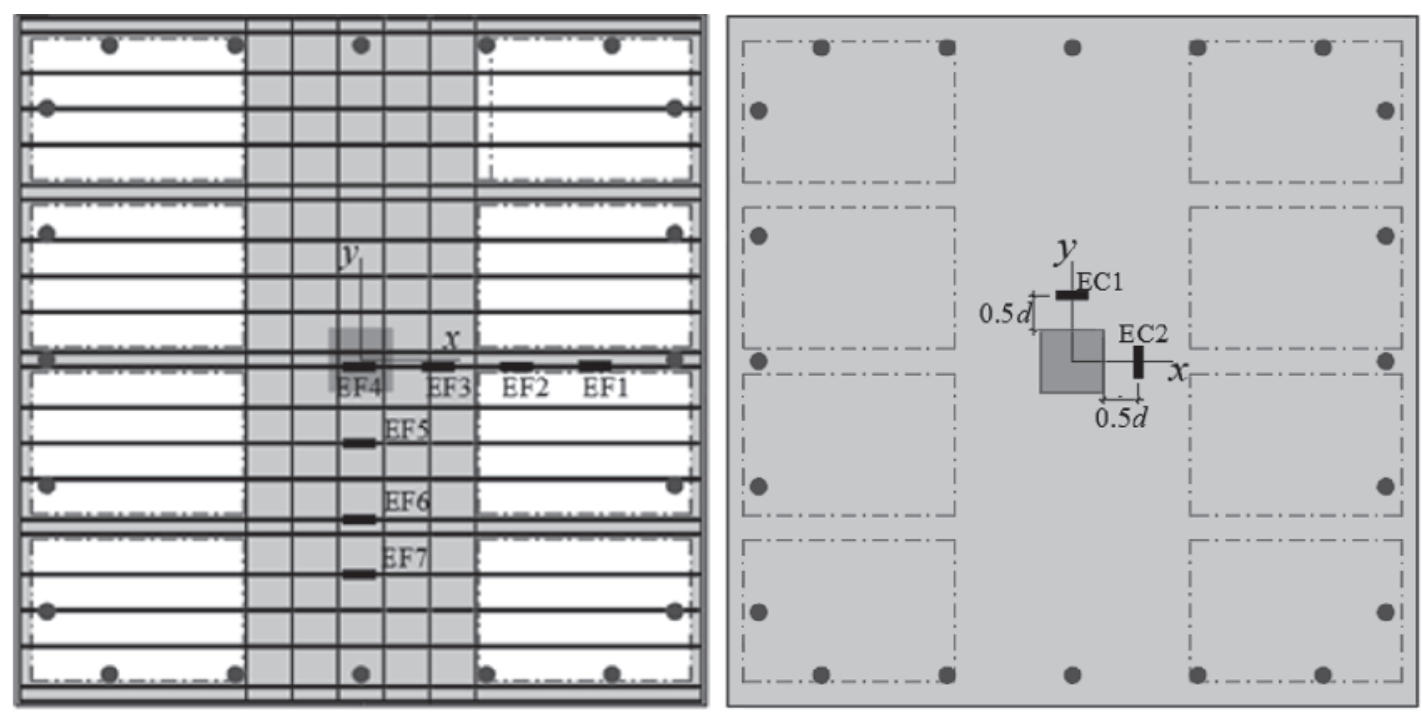

Figure 7

Positioning of the strain gages in reinforcement and concrete

fixed tangentially to the column at $x$ and $y$ directions (Figure 7). Two test systems were adopted, one for one-way slabs L1 and L2, in which the load was applied at the centre of the slabs with supports along the edges parallel to the wide beam, and another for two-way slabs L3 and L4, with loading at the four edges with supports at the centre of the slabs (Figure 8). The latter test system aimed at keeping the loading relation Pwide-beam/Pribs equal to 2 , where $P$ is the experimental loading.

\section{Experimental results}

\subsection{Vertical displacements}

Figure 9 shows L1 slab presented smaller displacements for the same loading level when compared to slab L2. Difference in behavior may be associated to the steel trusses on the ribs of slab L2, allowing larger displacements before failure. In relation to displacements of the two-way slabs, it was noted that the slab with the wide-beam of smaller depth, in this case slab L3, showed higher displacements when compared to slab L4, featuring a

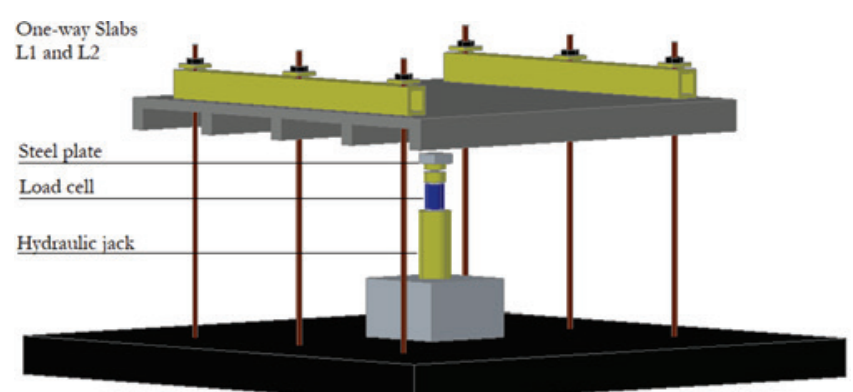

wide-beam $50 \mathrm{~mm}$ higher than L3. This is consistent, as the slab with the greater concrete cross section has a larger moment of inertia and hence greater rigidity for displacement. It is important to note that in the case of two-way slabs, the loading was applied at the edges and not at the centre of the slab. This explains the larger displacements recorded by the farthest dial gages from the slab centre. Consequently, increase of the wide-beam depth in reinforced concrete ribbed slabs during the design definitions prevents excessive displacements. However, increase has other implications for the slab, mainly with regard to the ribs' shear strength. This situation is generally not observed in several design cases since, in most cases, the spacing between the ribs is set within the range recommended by the design codes, where the shear strength of the ribs as beams need not be checked and the slab criteria may be adopted for the ribbed area.

Figure 10 shows displacements along the length of the slabs at both directions for load rates close to failure. Displacement results for one-way slabs revealed that displacements were larger at half span once the load was applied at the centre of the slab with supported edges. The two slabs reached the displacements limits

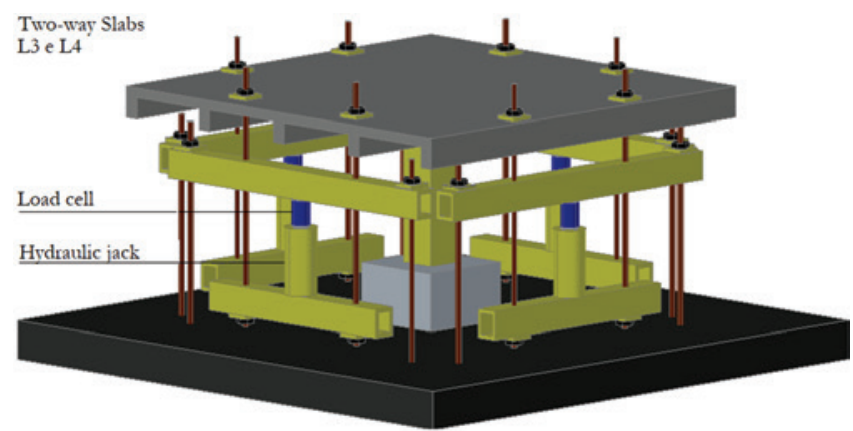

\section{Figure 8}

Test system 

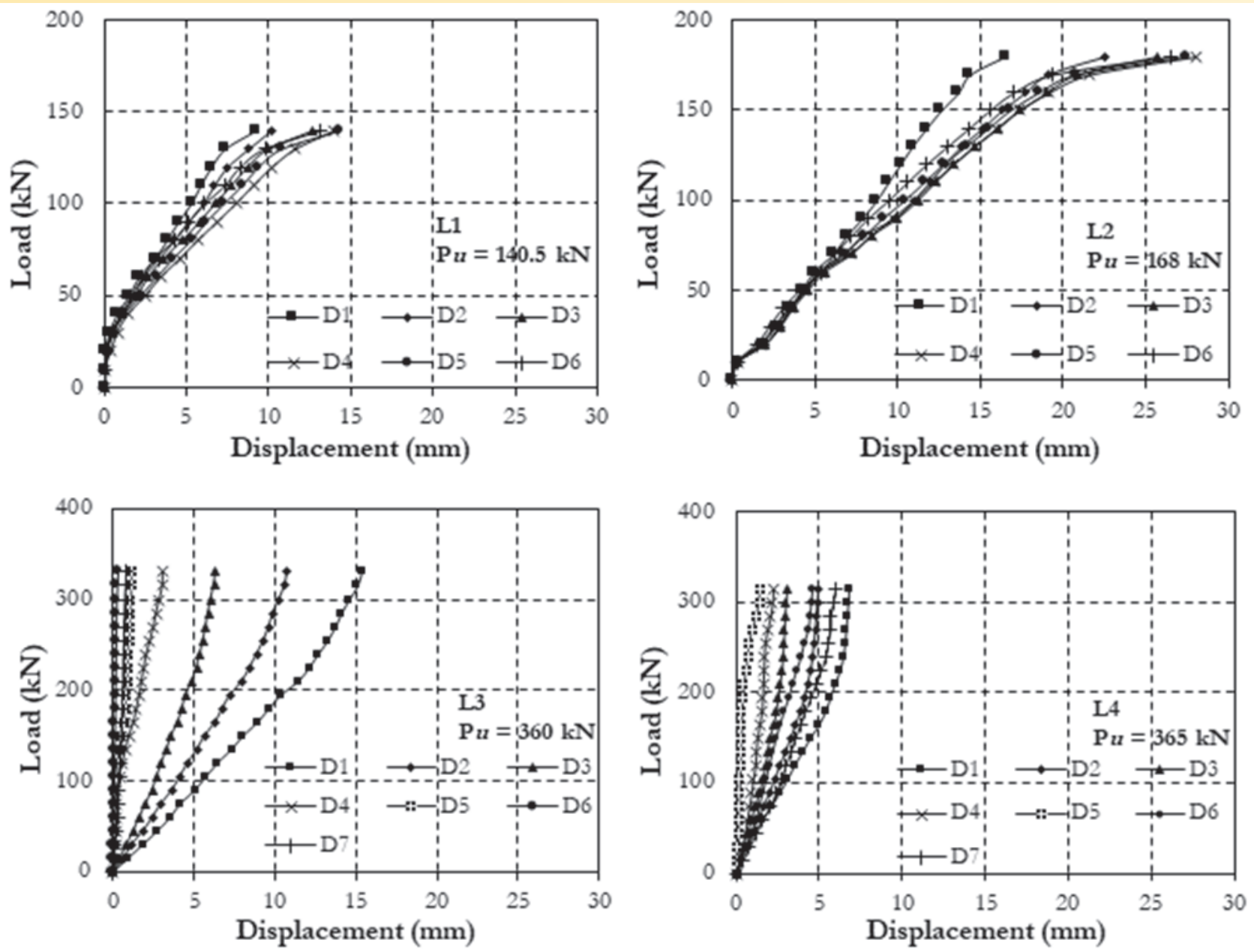

Figure 9

Slabs' displacements
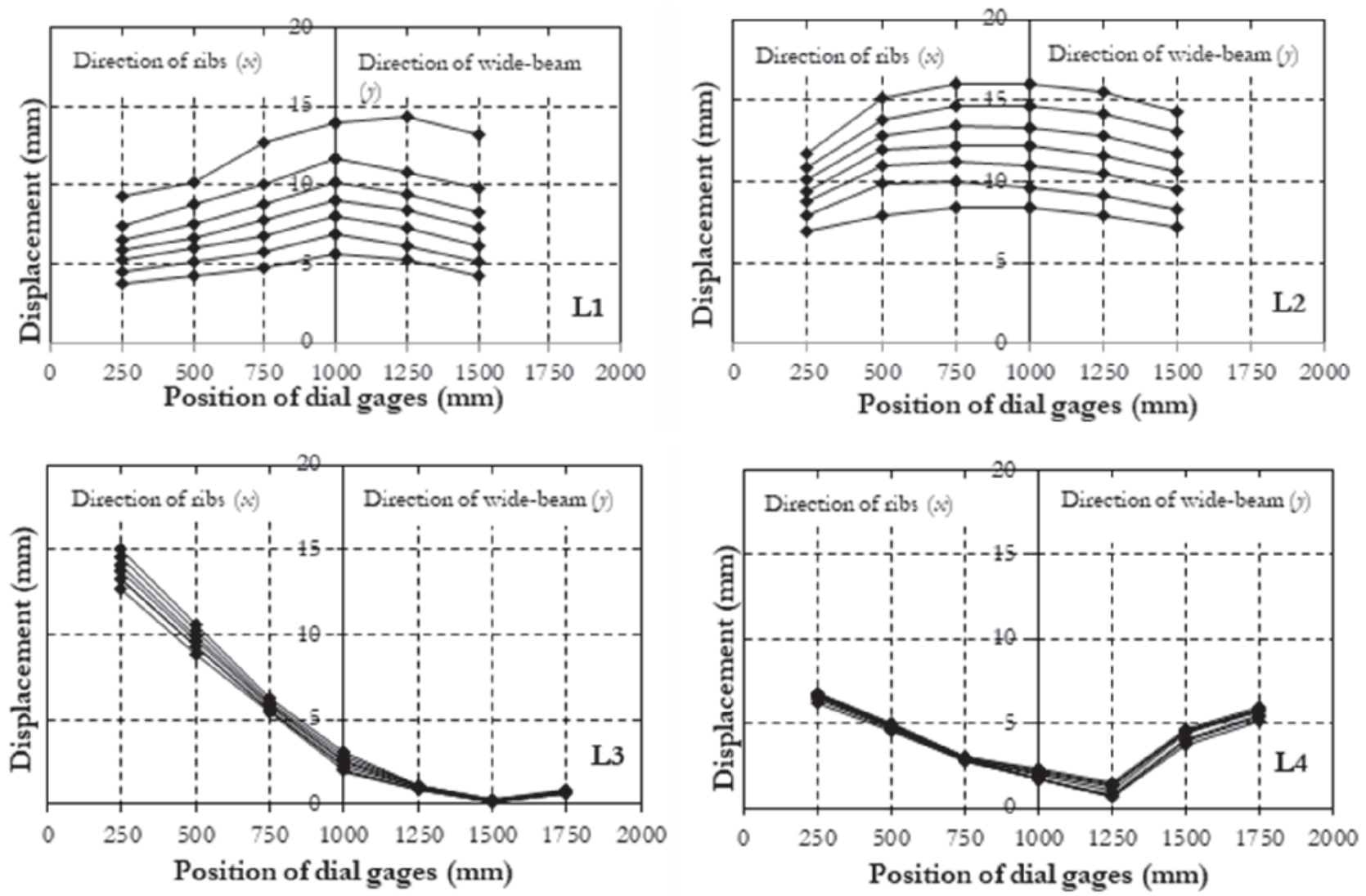

Figure 10

Displacements along the length of the slabs 
Reinforced concrete ribbed slabs with wide-beam
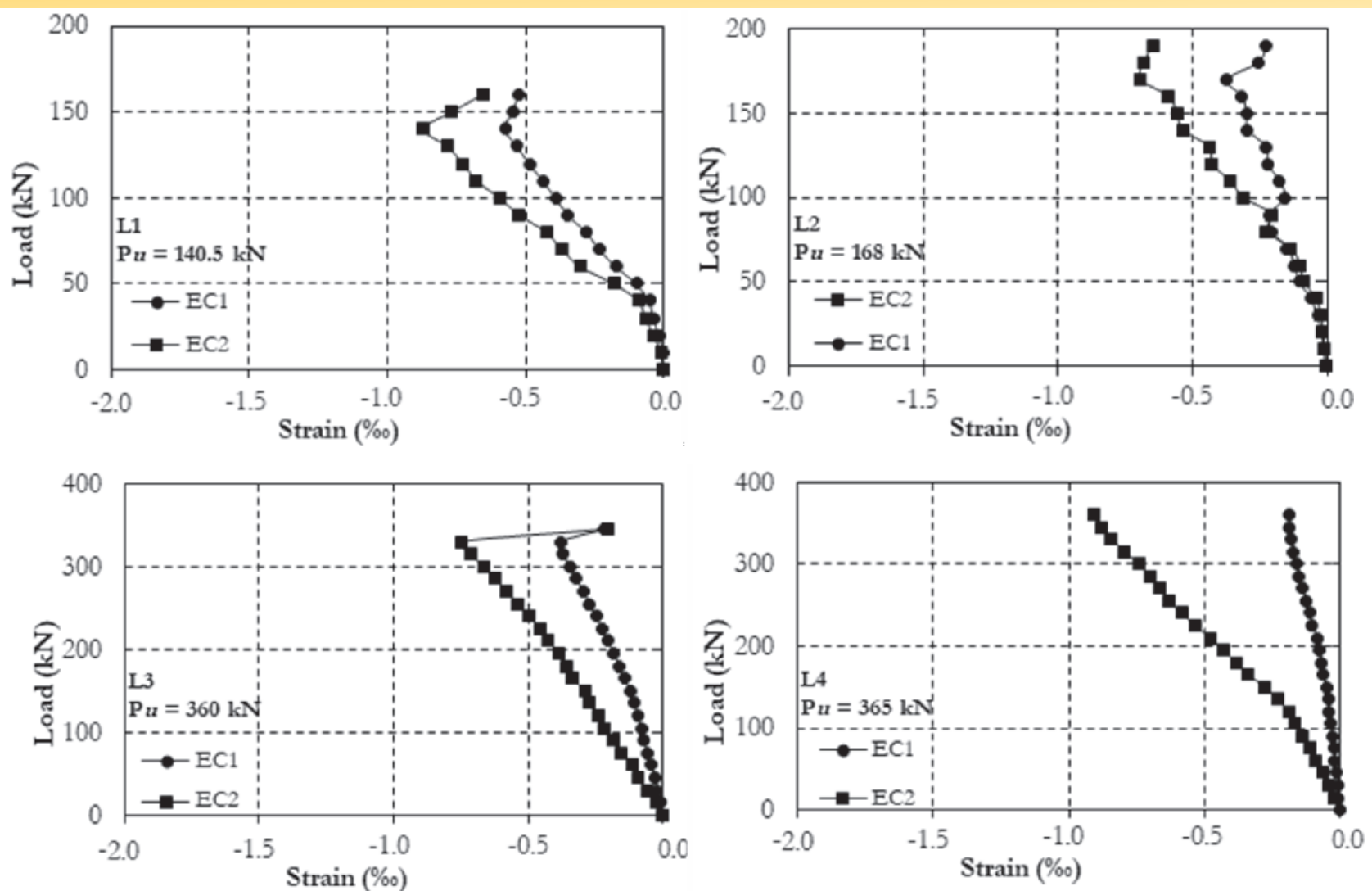

Figure 11

Slabs' concrete strains
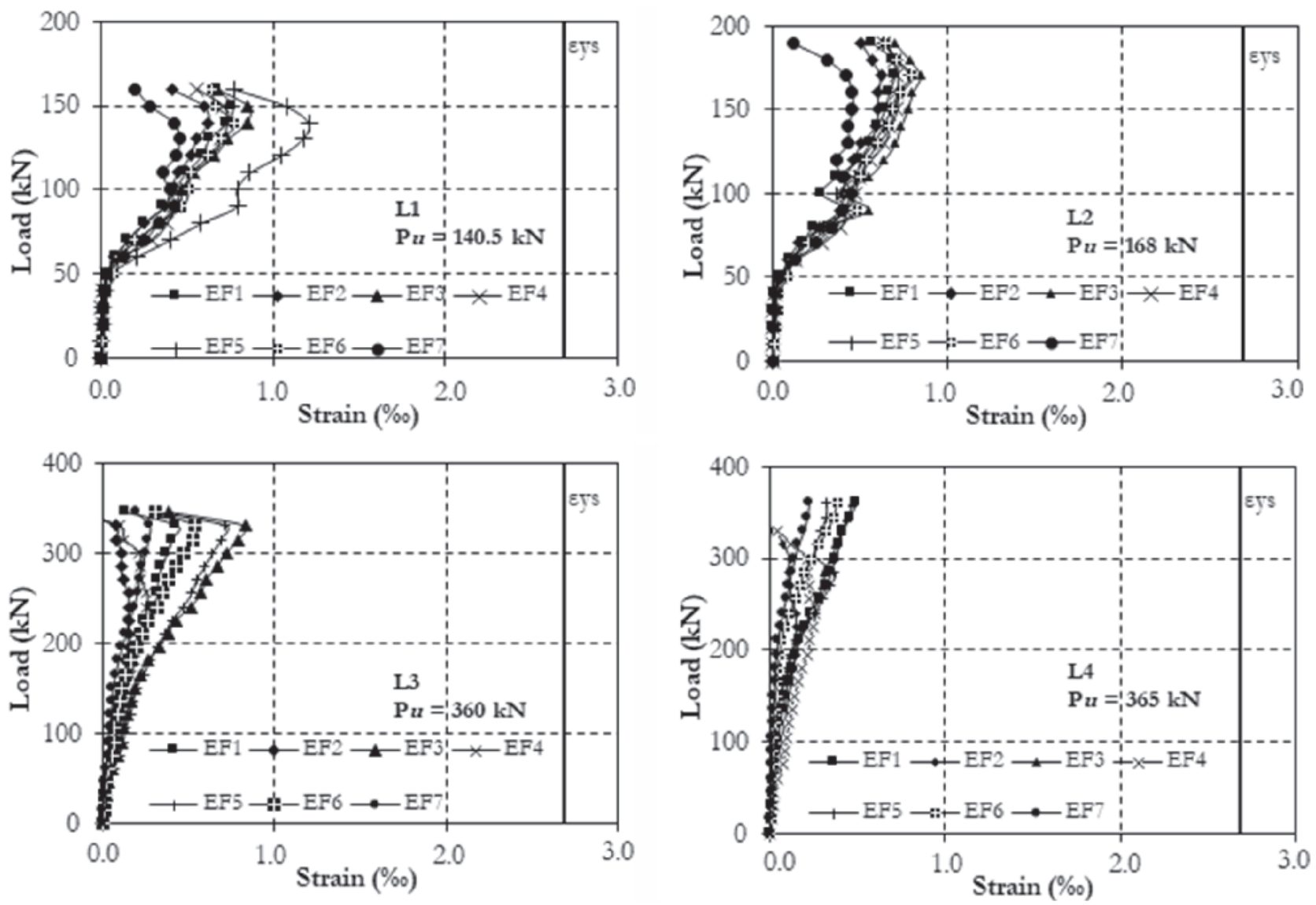

Figure 12

Slabs' bending reinforcement strains 
defined by standards in analyze (NBR and EC with $/ / 250$ and $\mathrm{ACl}$ with //250). For instance, L2 slab proved to have a more ductile behavior by the shear reinforcement in the ribs and reached double the displacement limit rate. This is a favorable point when comfort requirements, in addition to the safety requirements, for residential buildings are considered. From the point of view of security, i.e. in relation to the Ultimate Limit State, the results allow to evaluate that there is evidence that the presence of shear reinforcement in the ribs allowed more ductility with visible signs of imminent collapse. Therefore, shear reinforcement in the ribs becomes necessary even when the spacing between their axes is smaller or equal to the limit established by design codes. The displacements at the wide-beam $(y)$ direction for both two-way slabs showed very low rates (Figure 10) and did not reach the limit I/250. These slabs had a very rigid behavior attributed to wide-beam, avoiding large displacements at the two main directions.

\subsection{Concrete's strains}

Results given in Figure 11 for concrete strains demonstrate that rates close to the limit strain which characterizes concrete crushing were not observed. The largest strains were observed in the strain gauges positioned in the $x$ direction and close to $1.0 \%$. In the case of one-way slabs, results revealed that up to the loading level close to the cracking of L1 and L2 slabs (see Figure 11), the strains showed almost equal rates and, at the start of cracking, rates became different, with greater strain in the $x$ direction near the ribs. In the case of two-way slabs (L3 and L4), the concrete strains had different rates from the early stages of loading (see Figure 11). It is worth noting that, although loading on the direction of the wide-beam was equivalent to twice the loading in the $x$ direction, the stresses on the concrete in the tensile region were absorbed by the wide-beam flexure reinforcement avoiding a decrease in the depth of the neutral axis in this direction. In other words, the wide-beam-ribs connection ( $x$ direction) is a critical region, as there is a considerable difference in stiffness between the solid area and the region of the ribs.

\subsection{Flexural reinforcement's strains}

The flexural reinforcements' strains are shown in Figure 12 for oneway and two-way slabs, respectively. The wide-beam's flexural reinforcements placed in the $y$ direction were not monitored in current study due to the fact that analysis focused the behavior of the ribs when varying the depth of the wide-beam. As a rule, flexural reinforcement did not show strains corresponding to yielding, although there was excessive cracking in the tensioned region, mainly on L2, L3 and L4 slabs. Consequently, the ribs failed to demonstrate sufficient strength to compressive stress in the connection with the wide-beam. The above will be more fully discussed in the following topics on slabs' failure mode. Results show that more attention should be given to the connection especially when increasing the solid region around the column.

\subsection{Cracking pattern}

The slabs' cracking pattern showed a different behavior from that of solid flat slabs. In the case of solid slabs, the cracks usually started around the column and proceeded radially around the loaded area. When the radial cracks stabilized, the tangential cracks occurred, as noted by Oliveira [13]. In the case of ribbed slabs with widebeams, the first cracks appeared tangentially to the loaded area in wide-beam-ribs connection and then the radial cracks propagated with greater intensity, particularly in slabs L3 and L4. The slabs' cracking pattern is shown in Figure 13.

This cracking configuration in the upper region was also observed by Ajdukiewicz and Kliszczewicz [14] when they studied six ribbed slabs panels subjected to distributed loads: unlike the pattern of solid slabs, a tangential cracking pattern occurred at the loaded area. The experimentally verified fact made the authors adopt a yield line pattern to calculate the flexural strength of ribbed slabs, different from that adopted for solid slabs. It should be underscored that the
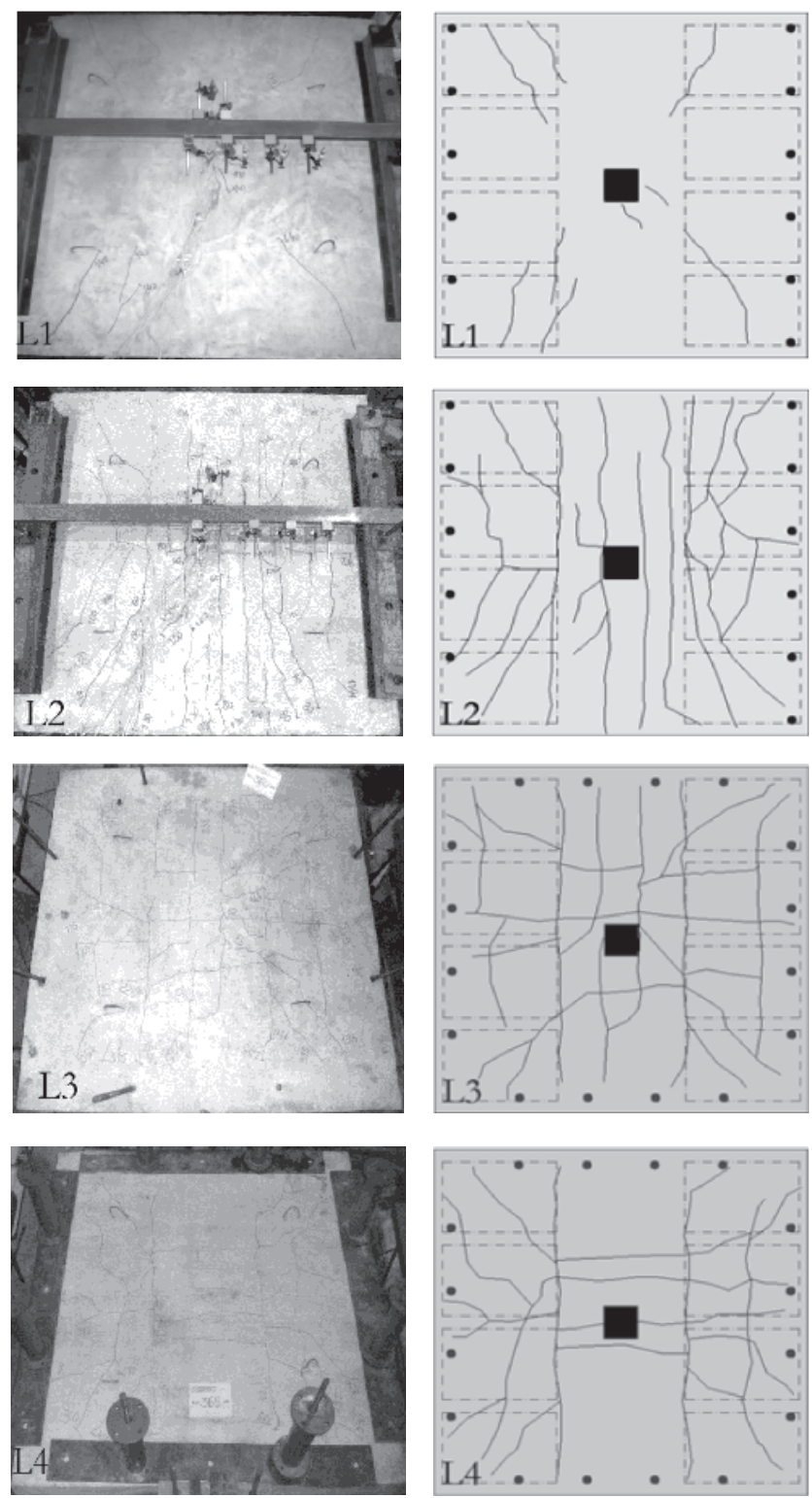

Figure 13

Slabs' cracking pattern 
Table 2

Slabs' failure modes

\begin{tabular}{|c|c|c|c|c|c|}
\hline Slab & $\mathrm{d}_{\text {nerv }}(\mathrm{mm})$ & $f_{c k}(M P a)$ & Ribs' shear reinforcement & $P_{u}(k N)$ & Failure mode \\
\hline L1 & \multirow{4}{*}{115} & \multirow{4}{*}{31} & - & 140.5 & \multirow{4}{*}{ Shear/ribs } \\
\hline L2 & & & \multirow{3}{*}{ TR $8644\left(38.6^{\circ}\right)$} & 168.0 & \\
\hline L3 & & & & 360.0 & \\
\hline L4 & & & & 365.0 & \\
\hline
\end{tabular}

ribbed slabs' mechanical behavior did not meet recommendations by codes ACI 318-83 [15] and CP 110-72 [16].

\subsection{Failure mode}

Table 2 presents the ultimate loads and failure modes of the slabs and Figure 14 shows the location where the failure surfaces. One failure cause located in the wide-beam-ribs connection may have been the excessive rotation of the ribs caused by bending effects, due to the difference between the wide beam and the ribs' stiffness. The wide-beam features high rigidity to rotation at the central region, mainly due to the great concrete contribution. However, this rigidity is considerably smaller in the ribbed region of
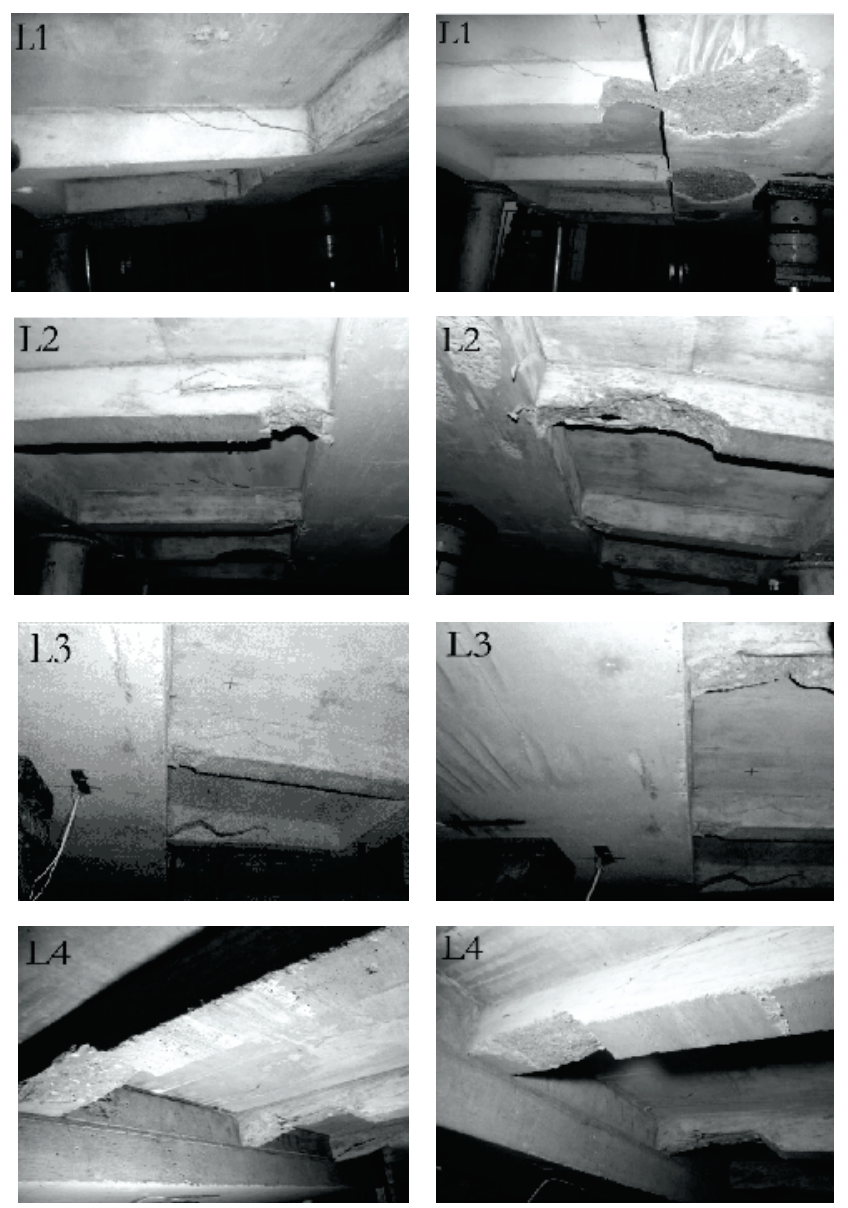

Figure 14

Slabs' failure mode the slabs, with higher rotations and large strains, causing concrete crushing in the ribs. The slabs' failure modes and ultimate load rates observed in current analysis reveal that they are governed by the shear strength of the ribs. In fact, all slabs failed by shear in the ribs. Even when the wide-beam depth increased, the rates of the ultimate load were close, as observed in slabs L3 and L4, and revealed that increase in the wide-beam depth at the central region reduces the displacements to increase the punching shear strength, even though it does not ensure a satisfactory performance on the ribs' behavior.

\section{Computational}

\subsection{Models' descripition}

Computational analysis comprised three ribbed slabs varying only in the depth of the wide-beam. Overall dimensions were $2200 \mathrm{~mm}$ sides (square slabs); the ribs were $150 \mathrm{~mm}$ depth; flange was 50 $\mathrm{mm}$ thickness and wide-beam depths featured $150 \mathrm{~mm}, 200 \mathrm{~mm}$ or $250 \mathrm{~mm}$. Since L1 and L2 slabs had the same depth for the widebeam, only one model was built; two other models were built for slabs L3 and L4. Based on the current experimental results, some definitions have been made for these models. Flange and ribs were modelled with shell surface elements, whilst the wide-beam and column were modelled with solid elements. The main objective was to analyses the stresses' distribution and identify the points with the greatest concentration to better understand the failure mechanism developed. Figure 15 provides a general model of the slabs.
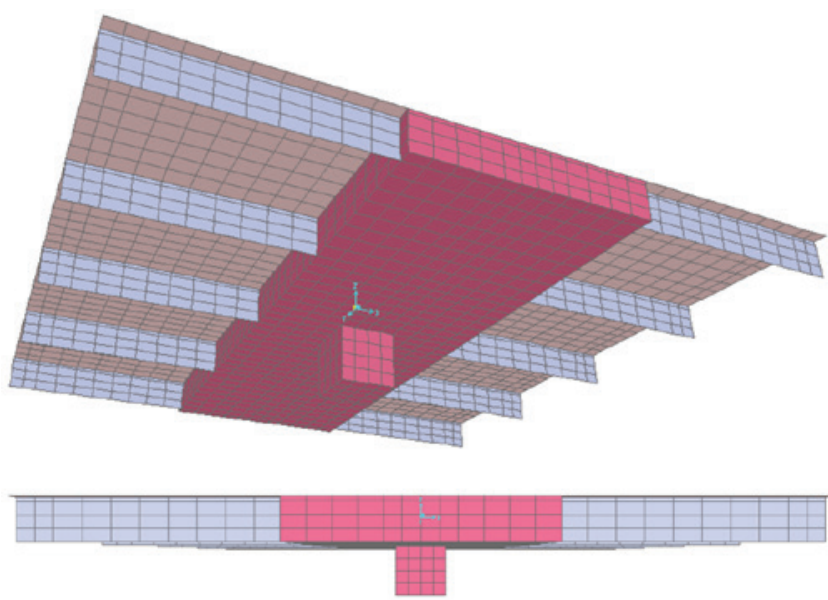

Figure 15

Slab's model with $250 \mathrm{~mm}$ depth wide-beam 

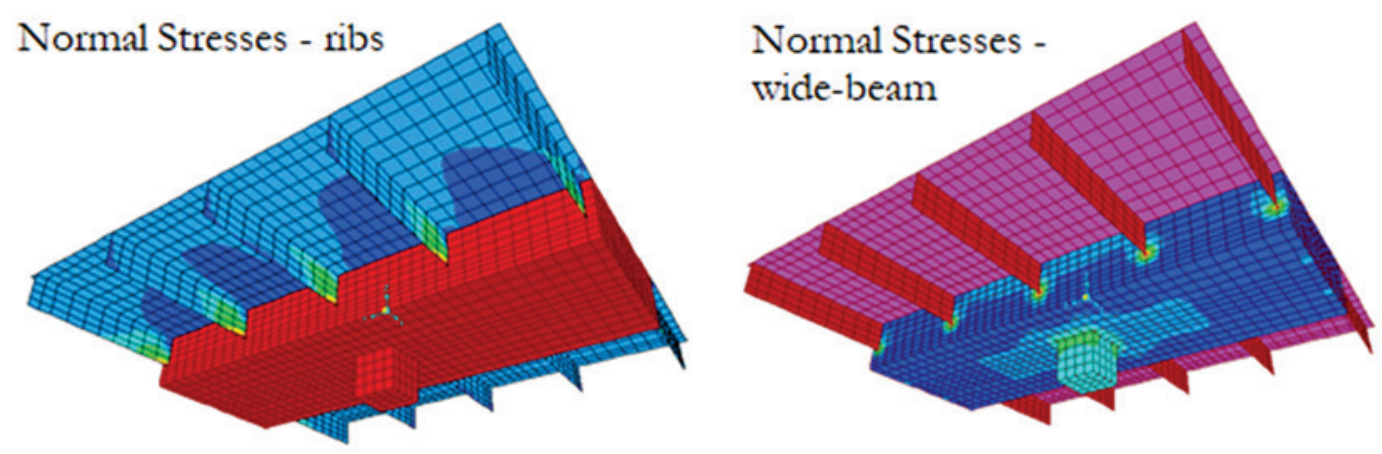

\section{Figure 16}

Normal stresses on two-way slab L4 with $250 \mathrm{~mm}$ depth wide-beam

The computational boundary conditions represented the experimental ones for one-way (L1 and L2) and two-way slabs (L3 and L4). Columns were supported to restrict movement in $z$ direction and avoid eccentricity effects that could cause unbalanced moments and lateral displacements. Unitary loads were applied along the edges of the slabs in the $z$ direction exactly where the steel rods were fixed, representing more closely the loading points during the experimental tests. The computational materials' mechanical properties were the same obtained experimentally, i.e. $f_{c k}$ of $31 \mathrm{MPa}, E c$ of $31.2 \mathrm{GPa}, f_{c t}$ of $2.9 \mathrm{MPa}$ and $\mathrm{v}$ (Poisson's ratio) equal to 0.2 . Analysis of computational results focused on the resistance of the wide-beam-column and wide-beam-ribs connections. Figure 16 shows the distribution of normal stresses on the ribs, column and wide-beam. Owing to the experimental failure modes, it was decided to concentrate attention in the normal stresses along the wide-beam-ribs connection.

\subsection{Results of computational analysis}

Computer results corroborated the experimental failure modes through the stress distribution. As may be perceived from the figures, the principal stresses were concentrated near the failure surfaces and clearly demonstrate that the wide-beam-ribs connection is the critical point in the design of ribbed slabs with wide-beam, regardless of the boundary conditions. In fact, failure modes in one-way and two-way slabs were almost similar and occurred by the exhaustion of the ribs' strength capacity. Figure 17 shows the force flow on the ribs' shell elements, indicating concentration of high compressive forces on the concrete bottom surface of the ribs. Further, high tension forces on the concrete top surface near the wide-beam generated large cracks and rotations of the ribs. This fact has been expected due to great stiffness of the wide-beam, leading to a premature failure of the ribs. The design stage should elicit a suitable stiffness to avoid this effect and ensure a good performance of the ribbed slabs with wide-beams.

\section{Analysis of codes' prescriptions}

In this section, the shear strength of the ribs as beams or slab and the punching shear strength of the wide-beam were all estimated according to codes ACI 318 [11], EC 2 [12] and NBR 6118 [5] and compared to experimental ultimate loads. The test system was adopted for two-way ribbed slabs L3 and L4, as mentioned before, in which the load applied in the $y$ direction (wide-beam) was twice the applied load in the $x$ direction (ribs). Furthermore, the flexural resistance of all slabs was calculated by the yield line theory and compared with the experimental results.

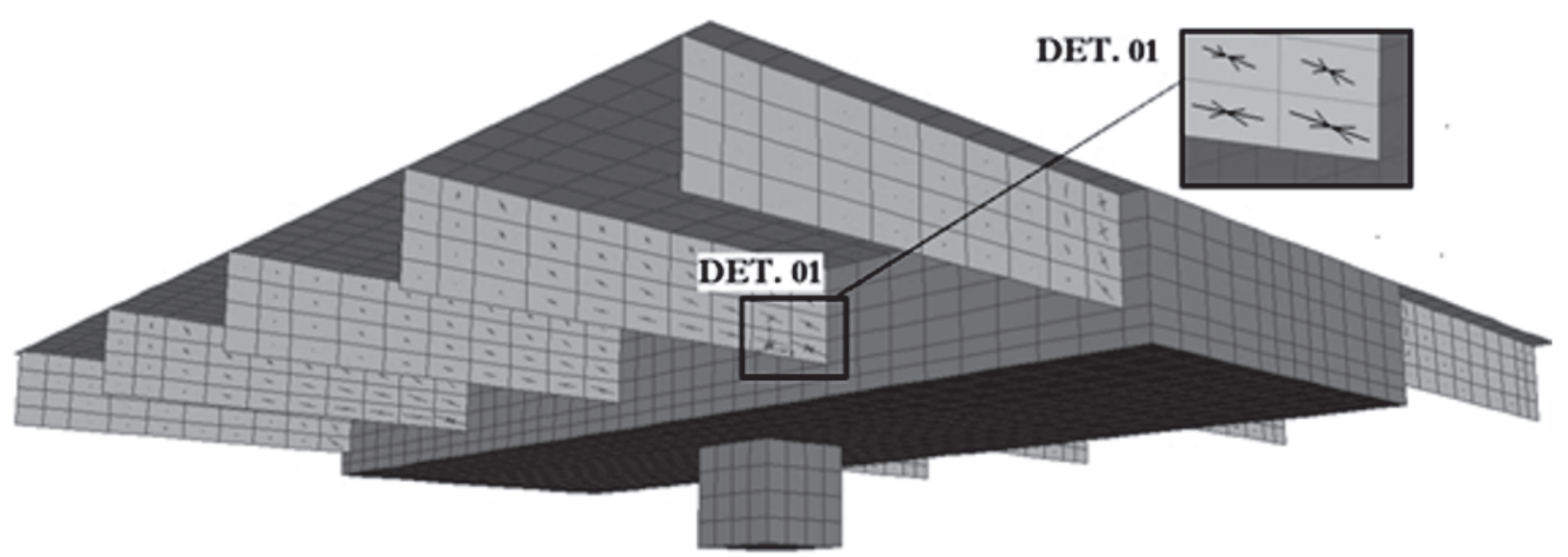

Figure 17

Load way in wide-beam-ribs connection 
Table 3

Shear strength estimates for ribs as beams

\begin{tabular}{|c|c|c|c|c|c|c|c|c|c|c|c|}
\hline Slab & $\begin{array}{c}d_{\mathrm{WB}} \\
(\mathrm{mm})\end{array}$ & $\begin{array}{c}d_{\text {rib }} \\
(\mathrm{mm})\end{array}$ & Ribs' shear reinforcement & $\begin{array}{l}\mathrm{P}_{\mathrm{u}}{ }^{*} \\
(\mathrm{KN})\end{array}$ & $\begin{array}{c}\mathbf{P}_{\text {u ribs }} * * \\
(\mathrm{kN})\end{array}$ & $\begin{array}{c}\mathrm{P}_{\mathrm{u}} \mathrm{ACl} \\
(\mathrm{kN})\end{array}$ & $\begin{array}{l}\mathbf{P}_{\mathrm{u} \mathrm{ribs}} \\
/ \mathbf{P}_{\mathrm{u} \mathrm{ACl}}\end{array}$ & $\begin{array}{l}P_{u} E C \\
(k N)\end{array}$ & $\begin{array}{l}P_{u} \text { ribs } \\
/ P_{u} \text { EC }\end{array}$ & $\begin{array}{c}P_{u} \text { NBR } \\
(k N)\end{array}$ & $\begin{array}{c}\mathbf{P}_{\mathrm{u} \text { ribs }} \\
/ \mathrm{P}_{\mathrm{u}} \mathrm{NBR}\end{array}$ \\
\hline L1 & 115 & \multirow{4}{*}{115} & - & 140.5 & 140.5 & 85.0 & 1.65 & 120.0 & 1.17 & 160.0 & 0.88 \\
\hline L2 & 115 & & \multirow{3}{*}{ TR $8644\left(38.6^{\circ}\right)$} & 168.0 & 168.0 & \multirow{3}{*}{98.0} & 1.71 & \multirow{3}{*}{131.0} & 1.29 & \multirow{3}{*}{176.0} & 0.95 \\
\hline L3 & 176 & & & 360.0 & 120.0 & & 1.22 & & 0.92 & & 0.68 \\
\hline L4 & 226 & & & 365.0 & 121.7 & & 1.24 & & 0.93 & & 0.69 \\
\hline
\end{tabular}

Table 4

Shear strength for solid slab according to NBR 6118 (ABNT, 2014)

\begin{tabular}{|c|c|c|c|c|c|c|c|c|}
\hline Slab & $\begin{array}{c}d_{\text {rib }} \\
(\mathrm{mm})\end{array}$ & $\begin{array}{c}\mathrm{d}_{\mathrm{eq}}{ }^{*} \\
(\mathrm{~mm})\end{array}$ & Ribs' shear reinforcement & $\begin{array}{l}\mathbf{P}_{\mathrm{u}}{ }^{*} \\
(\mathrm{kN})\end{array}$ & $\begin{array}{c}\text { P NBR } \\
\mathrm{d}_{\text {rib }} * * \\
(\mathrm{kN})\end{array}$ & $\mathrm{P}_{\mathrm{u}} / \mathrm{d}_{\mathrm{rib}} \mathrm{PNBR}$ & $\begin{array}{l}\text { P NBR } d_{\text {eq }} \\
(k N)\end{array}$ & $\mathbf{P}_{\mathrm{u}} / \underset{\mathrm{d}_{\mathrm{req}}}{\mathrm{PNBR}}$ \\
\hline L1 & \multirow{4}{*}{115} & \multirow{4}{*}{59} & - & 140.5 & \multirow{4}{*}{316.2} & 0.44 & \multirow{4}{*}{210.1} & 0.67 \\
\hline L2 & & & \multirow{3}{*}{ TR $8644\left(38.6^{\circ}\right)$} & 168.0 & & 0.53 & & 0.80 \\
\hline L3 & & & & 360.0 & & 1.14 & & 1.71 \\
\hline L4 & & & & 365.0 & & 1.15 & & 1.74 \\
\hline
\end{tabular}

\subsection{Shear strength}

Shear strength was calculated when the ribs were considered as isolated beam or as solid slab with the overall width of the ribbed slab. Tables 3 and 4 provide the estimates. Slabs shown in Table 3 have a type of failure by exhausting the shear resistance of the ribs. In the case of the one-way ribbed slabs $L 1$ and $L 2$, the estimates of shear strength by codes EC 2 [12] and ACI 318 [11] revealed conservative rates, particularly code $\mathrm{ACl}$ with maximum result $70 \%$ of the experimental failure load. The Brazilian code also provided results below the failure load rates for the slabs, up to $12 \%$. ACl 318 [11] prescriptions were once more conservative for the two-way slabs L3 and L4 in the direction of the ribs, but rates were close to the ultimate load. EC 2 [12] code presented results around $9 \%$ under the experimental load rates for these slabs, whereas the Brazilian code revealed unsafe results, with a $30 \%$ critical rate beyond the experimental failure load. The above shows a change in rib strength according to the support conditions. This unsafe behavior may be due to the torsion effect in the region of the wide-beam near the connection with the ribs, which is strong enough to produce early rib failure.

Although the two-way slabs had a higher failure load when compared to one-way slabs, especially by the contribution of the wide-beam ( $y$ direction), the loading over the ribs of the slabs supported along the four edges ( $L 3$ and L4) was lower than in slabs supported in one direction ( $\mathrm{L} 1$ and $\mathrm{L} 2$ ). This confirms the fact that, regardless of the support conditions, not only the solid region of connection with the column, but also the ribs become crucial in the design of ribbed slabs with wide-beam. As mentioned above, the Brazilian code suggests that the region of the ribs should be verified to shear according to the slab criteria since the spacing between their axes is less than $650 \mathrm{~mm}$. Table 4 shows the theoretical rates for shear strength at this region as solid slab, compared to the experimental results for failure load. The estimated rates of shear strength were calculated with two rates of effective depth. The first considered the effective depth of the ribs $\left(d_{r i b}\right)$ whilst the second considered the equivalent effective depth $\left(d_{\text {eq }}\right)$, calculated as a function of equivalent depth, in which an equivalence of stiffness between a solid slab and a ribbed slab is undertaken. The above analyses reveal imprecisions in the code's prescriptions for oneway and two-way ribbed slabs with wide-beam. Another point to be underscored is that it is essential to differentiate calculating the strength of ribbed slabs according to the support condition since the use of solid slab criteria for one-way slabs did not give satisfactory results.

\subsection{Punching shear strength}

Table 5 showed that none of the slabs failed by punching shear. Two situations contributed to the fact. The first is related to shear

\section{Table 5}

Punching shear strength according to design codes

\begin{tabular}{|c|c|c|c|c|c|c|c|c|c|}
\hline Slab & $\begin{array}{c}\mathrm{d}_{\mathrm{WB}} \\
(\mathrm{mm})\end{array}$ & $\begin{array}{c}f_{c k} \\
(\mathrm{MPa})\end{array}$ & $\begin{array}{c}P_{u} \\
(k N)\end{array}$ & $\begin{array}{l}\mathrm{P}_{\mathrm{PS}} \mathrm{ACl} \\
(\mathrm{kN})\end{array}$ & $\begin{array}{c}\mathbf{P}_{\mathrm{u}} / \mathbf{P}_{\mathrm{PS}} \\
\mathrm{ACl}\end{array}$ & $\begin{array}{l}P_{\mathrm{PS}} \mathrm{EC} \\
(\mathrm{kN})\end{array}$ & $\begin{array}{c}P_{u} / P_{P S} \\
E C\end{array}$ & $\begin{array}{c}P_{\mathrm{PS}} \mathrm{NBR} \\
(\mathrm{kN})\end{array}$ & $\begin{array}{c}P_{\mathrm{u}} / \mathbf{P}_{\mathrm{PS}} \\
\mathrm{NBR}\end{array}$ \\
\hline L1 & 115 & \multirow{4}{*}{31} & 140.5 & 268.9 & 0.52 & 297.8 & 0.47 & 345.3 & 0.41 \\
\hline L2 & 115 & & 168.0 & 268.9 & 0.62 & 297.8 & 0.56 & 345.3 & 0.49 \\
\hline L3 & 176 & & 360.0 & 491.3 & 0.73 & 611.4 & 0.59 & 631.5 & 0.57 \\
\hline L4 & 226 & & 365.0 & 714.7 & 0.51 & 920.7 & 0.40 & 920.7 & 0.40 \\
\hline
\end{tabular}


Table 6

Flexural strength estimated by yield lines theory

\begin{tabular}{|c|c|c|c|c|c|c|c|c|}
\hline Slab & $\begin{array}{c}d_{\text {rib }} \\
(\mathrm{mm})\end{array}$ & $\begin{array}{c}d_{e q} \\
(\mathrm{~mm})\end{array}$ & $\begin{array}{c}f_{\text {ck }} \\
(M P a)\end{array}$ & $\begin{array}{c}P_{u} \\
(k N)\end{array}$ & $\begin{array}{l}P_{\text {flex }} \\
(\mathrm{kN})\end{array}$ & $\mathbf{P}_{\mathrm{u}} / \mathbf{P}_{\text {flex }}$ & $\begin{array}{l}P_{\text {flex }} d_{\text {eq }} \\
(k N)\end{array}$ & $\begin{array}{c}\mathbf{P}_{\mathrm{u}} / \mathbf{P}_{\text {flex }} \\
\mathbf{d}_{\mathrm{eq}}\end{array}$ \\
\hline L1 & \multirow{4}{*}{115} & \multirow{4}{*}{59} & \multirow{4}{*}{31} & 140.5 & 289.8 & 0.48 & 165.9 & 0.85 \\
\hline L2 & & & & 168.0 & 289.8 & 0.58 & 165.9 & 1.01 \\
\hline L3 & & & & 360.0 & 550.7 & 0.65 & 359.1 & 1.00 \\
\hline L4 & & & & 365.0 & 672.0 & 0.54 & 469.4 & 0.78 \\
\hline
\end{tabular}

and flexural resistance of the ribs which is lower than the punching strength, whilst the second is the combination of large cracks in the tensioned region along the wide-beam-ribs connection with excessive rotation of the ribs, leading to concrete crushing in the slab's compressed region. The other contributing factor to avoid punching shear failure is related to the shear reinforcement contribution used in the wide-beam. Undoubtedly, all these elements helped to distribute the shear forces outside the widebeam region, corroborating the shear failure of the ribs.

\subsection{Flexure strength}

Table 6 presents the relationship between the ultimate load of slabs and the estimated results according to the yield line theory. These theoretical results considered two rates for the effective depth in the flexural strength calculation. The first considers the effective depth of the ribs and the second the equivalent effective depth. In general, the flexural strength was higher than the failure loads since a flexural failure was not desired. Current analysis focused on the shear strength of slabs. Even the behavior of the materials monitored by instruments showed a low level of strain, especially flexural reinforcement, which, otherwise, would make it possible to classify failure modes by flexure. It is known that the exhaustion of the bearing capacity of a structure, which hypothetically may occur, should be preferably by flexure, avoiding a brittle and sudden failure by shear. However, doubts on the real behavior of ribbed slabs fail to precise the occurrence of this rule.

\section{Conclusions}

Although few tests were carried out, important issues on the structural behavior of two and one-way reinforced concrete ribbed slabs with wide-beam could be solved. Boundary conditions affect the structural slabs' behavior and modify significantly the performance of the slabs. They should be taken into account in resistance estimates. Experimental results also showed that increasing wide-beam depth provided smaller displacements and the shear reinforcement in the ribs provided a more ductile behavior when compared to the slab without it (L1). Concrete and steel have low strain rates due to the premature failure of the ribs by shearing. The cracking pattern was different from that of the solid flat slab, with large longitudinal cracks along the tensioned surface of the wide-beam-ribs connection. The ribs' concrete started to crush under this connection, corroborating the shear failure. The wide-beam-ribs' connection proved to be one of the critical points in the design of reinforced concrete ribbed slabs, especially when the wide-beam's depth increased.

The computational analysis helped to better understand the slabs behavior and indicated that the wide-beam-ribs connection would have a higher loading level when compared to the wide-beamcolumn connection. This behavior met the experimental one, but the codes' estimates were generally conservative, except in the case of NBR 6118 [5] which presented unsafe results against safety, especially for two-way slabs. However, this code presented more accurate results by treating the region of the ribs as slab when supported in the two perpendicular directions. In general, there are still many uncertainties on the structural system with ribbed slabs. In certain situations, approaches to the behavior of solid slabs are not suitable. However, current investigation provided conditions to assess more accurately the behavior of this type of slab. Further studies are needed to provide a better understanding on the system, especially with regard to the wide-beam-column and the wide-beam ribs connection.

\section{Acknowledgements}

The authors would like to thank CNPq, CAPES and IPEAM for their financial support to develop current research.

\section{References}

[1] Schwetz, P. F., Gastal, F. P. S. L. and Silva Filho, L. C. P. (2013) Numerical and experimental study of a waffle slab designed to serve as a tennis court floor. IBRACON Structures and Materials Journal, Volume 6, Number 3, pp. 375-391.

[2] Macgregor, J. G. and Wight, J. K. (2006) Reinforced Concrete: Mechanics and Design. Sixth Edition. New Jersey. Pearson Education.

[3] Climent, A. B. and Ávila, J. D. (2014) Moment transfer and influence of transverse beams in interior waffle flat platecolumn connections under lateral loading. Engineering Structures, Volume 49, pp. 146-155.

[4] Lau and Clark, Shear transfer between ribbed slab and internal column. Magazine of Concrete Research, 2007, 59, No. 7, September, 507-516

[5] Brazilian Association of Technical Standards (ABNT). NBR 6118 [5] - Design and execution of reinforced concrete buildings. Rio de Janeiro.

[6] Soares, Y. V.; Oliveira, D. R. C.; Melo, G. S. S. A. (2006) Design of RC ribbed flat slabs to shear according to codes NBR 6118:1978, NBR 6118:2003 e CEB-FIP Model Code:1990. In: $48^{\circ}$ Brazilian congress on concrete, 2006, Rio de Janeiro. Ibracon, São Paulo, 2006. v.1. p.1-16. 
[7] Souza, S. S. M.; Oliveira, D. R. C. (2011) Reinforced concrete waffle flat slabs under shearing. IBRACON Structures and Materials Journal, Volume 4, Number 4, pp. 610-641.

[8] Albuquerque, N. G. B. and Oliveira, D. R. C. (2016) Ribbed flat slabs of RC with solid area variable: a numerical and experimental analysis. 1. ed. Saarbrückenm-Germany: New Academic Issues, OmniScriptum GmbH \& Co. KG, 2016. v. 1. $192 p$.

[9] Souza, W. M., Caetano, T. R. G., Ferreira, M. P. and Oliveira, D. R. C. (2014) Shear strength of one-way reinforced concrete ribbed slabs. IBRACON Structures and Materials Journal, Volume 7, Number 4, pp. 648-684.

[10] Al-Bayati, A. F., Lau, T. L., and Clark, L. A. (2015) Concentric Punching Shear of Waffle Slab. ACl Structural Journal, Volume 112, No. 5, September-October 2015.

[11] ACl-318R (2008) Building Code Requirements for Structura Concrete, American Concrete Institute, Farmington Hills, Michigan.

[12] Eurocode 2 (2004) Design of Concrete Structures, Part 1, General codes and codes for buildings, DD ENV, British Codes Institution, London.

[13] Oliveira, D. R. C., Melo, G. S. S. A., and Regan, P. E. (2004). Punching resistance of RC slabs with rectangular columns. Magazine of Concrete Research, Volume 56, Issue 3, April 2004, pp. 123-138.

[14] Ajdukiewicz, A. B. and Kliszczewicz, A. T. (1986) Experimental Analysis of Limit States in a Six-Panel Ribbed Flat Plate Structure. ACI Journal, Technical Paper, pp. 83-78, November-December.

[15] ACl Committee 318 (1983) Building Code Requirements for Reinforced Concrete (ACl 318-83), American Concrete Institute, Detroit.

[16] CP 110-72 (1972) Code of Practice for the Structural Use of Concrete (CP 110: Part 1: 1972), British Codes Institution, London, $154 \mathrm{pp}$. 